\title{
Isolation and Characterization of Phytase from Chicken Manure Bacteria
}

\author{
Mega Pratiwi Irawan* and Zeily Nurachman \\ Biochemistry Research Division, Mathematic and Natural Science Faculty, \\ Institut Teknologi Bandung, Jalan Ganesha 10, Bandung 40132, Indonesia
}

Diterima 14-06-2013Ｄisetujui 18-06-2013

\begin{abstract}
Cereals in animal feed contain anti-nutrients of phytic acid that has capability of chelating proteins and cations. Phytase can be employed to reduce phytic acid through hydrolyzing phytic acid into free phosphate group and lower derivate of inositol phosphate. The aim of the study was to isolate and characterize phytase obtained from chicken manure bacteria. The study included the screening of phytase-producing bacteria from chicken manure, the homology analysis of bacterium, and the determination of phytase activity. Phytase activity was measured from concentration of free phosphate. The results showed that one phytase-producing isolate obtained from chicken manure grew in the medium containing $5 \%$ rice bran extract at $37^{\circ} \mathrm{C}$ for $5 \mathrm{~d}$. Based on a phylogeny is tree analysis of the genes related to $16 \mathrm{~S}$ rRNA, the isolate was identified as Acinetobacter sp. TZ1. The extracellular phytase expressed by Acinetobacter $\mathrm{sp}$. TZ1 exhibited optimum reactions at $\mathrm{pH}$ 5 and $50^{\circ} \mathrm{C}$. The enzyme showed activity of $64,6 \mathrm{nmol} \mathrm{mL}-1 \mathrm{~min}^{-1}$ and specific activity of $236 \mathrm{nmol} \mathrm{min}^{-1} \mathrm{mg}^{-1}$. Relative molecular mass of phytase TZ1 was $\sim 35 \mathrm{kDa}$. Phytase obtained is potential to improve animal feed quality by hydrolyzing phytic acid.
\end{abstract}

Keywords: chicken manure bacteria, phytase, rice bran

\begin{abstract}
ABSTRAK
Biji-bijian yang terdapat dalam pakan ternak mengandung zat antinutrisi berupa senyawa asam fitat (inositol fosfat) yang mampu membentuk kompleks dengan protein dan kation. Fitase dapat dipakai untuk mengurangi asam fitat dalam pakan ternak dengan cara menghidrolisis asam fitat menjadi fosfat dan derivat inositol fosfat yang lebih rendah. Tujuan dari penelitian ini adalah mengisolasi dan mengkarakterisasi fitase dari bakteri feses ayam. Metode penelitian yang dilakukan adalah isolasi dan penapisan bakteri dari feses ayam, penentuan hubungan kekerabatan bakteri, serta penentuan aktivitas enzim. Aktivitas fitase diperoleh dengan cara menghitung fosfat bebas yang terbentuk setelah reaksi enzimatis. Hasil penapisan bakteri dari feses ayam menghasilkan isolat bakteri yang mampu memproduksi fitase pada medium tumbuh ekstrak bekatul $5 \%$ pada $37^{\circ} \mathrm{C}$ selama 5 hari. Berdasarkan analisis filogeni urutan gen $16 \mathrm{~S}$ rRNA, isolat bakteri tersebut diidentifikasi sebagai Acinetobacter sp. TZ1. Fitase yang dihasilkan Acinetobacter sp. TZ1 merupakan enzim ekstrasel dan memiliki aktivitas optimum pada $\mathrm{pH} 5$ dan $50^{\circ} \mathrm{C}$ dengan unit aktivitas sebesar $64,6 \mathrm{nmol} \mathrm{mL} \mathrm{min}^{-1}$ dan aktivitas spesifik 236

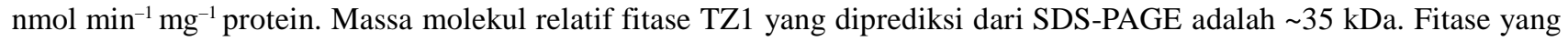
dihasilkan berpotensi untuk meningkatkan kualitas nutrisi pakan melalui hidrolisis asam fitat.
\end{abstract}

Kata Kunci: bakteri feses ayam, bekatul, fitase

\footnotetext{
*Telp: +6281371010023

Email:mp.irawan@gmail.com
} 


\section{INTRODUCTION}

Animal feed is made from grains which contain phytic acid (myo-inositol hexakisphosphate) (Kerovuo et al. 1998). Phytic acid act as anti-nutritional agent in animal body due to its ability to form chelates with amilase and cations such as $\mathrm{Ca}^{2+}, \mathrm{Fe}^{2+}, \mathrm{Mg}^{2+}$ and $\mathrm{Zn}^{2+}$ (Bohn et al. 2008; Raghavendra \& Halami 2009). Adding inorganic phosphate to fulfill animal nutrition is needed to increase feed stock quality. However, inorganic phosphate addition into animal feed may raise water body pollution near to live stock (eutrophication), algal bloom, and water animal death (Bohn et al. 2008). Therefore, an enzyme is required to hydrolize and decrease anti-nutritional effect of phytic acid so that raising the bioavailability of phosphate and cations (Raghavendra \& Halami 2009; Kerovuo et al. 2000).

The feed and food can influence the type of microbes that live in animal and human digestion track (Tremaroli \& Bäckhed 2012). Chicken feed consists of grains which contain phytic acid, so that it is needed to screen chicken manure bacteria with the assumption that there is phytic acid-hydrolizing bacteria in chicken manure. The aims of this study were to screen phytase-producing bacteria in chicken manure for hydrolizing phytic acid, to identify bacteria type through $16 \mathrm{~S}$ rRNA gene analysis, and to characterize phytase activity of chicken manure bacteria.

\section{MATERIALS AND METHODS}

Screening of Phytase-Producing Bacteria from Chicken Manure. Chicken manure (1 g) was diluted gradually into $100 \mathrm{~mL} \mathrm{NaCl} 0,85 \%$ solution. $100 \mathrm{~mL}$ solution was pipetted and spread on the $5 \%$ rice brand extract solid medium. The medium was incubated at $37^{\circ} \mathrm{C}$ for $2 \mathrm{~d}$. Bacteria which grown on the medium were streaked on fresh medium and incubated at $37^{\circ} \mathrm{C}$ for $2 \mathrm{~d}$. Single colony of bacteria that was grown on the surface of $5 \%$ rice bran extract medium were grown on fresh solid medium at $37^{\circ} \mathrm{C}$ for $5 \mathrm{~d}$. Phytase activity was qualitatively identified by coloring the solid medium surface of bacterial growth (Bae et al. 1999). Phytase-producing bacteria was identified by clearing zone appearance after coloring assay.

Sequencing of 16s rRNA Gene and Bacterial Genetic Relationship. Bacterial DNA chromosome was isolated by Wizard® Genomic DNA Purification Kit and amplified by
PCR (primer BactF1 and UniB1) for 30 cycles and the DNA ribbons were visualized by gel electroforesis. Sequencing of 16S rRNA gene from phytase-producing bacteria was done by Macrogen Korea. Bacterial identification was implemented by comparing $16 \mathrm{~S}$ rRNA nucleotide from isolated bacteria with GeneBank data using BLAST on www.ncbi.nlm.nih.gov. Phylogeny tree was created using ClustalX which based on alligning several bacterial 16S rRNA nucleotide and genetic relationship was visualized by TreeView.

Bacterial Growth and Cultivation. Single colony was grown on 5\% rice brand extract liquid medium in shaker incubator at $37^{\circ} \mathrm{C} 150 \mathrm{rpm}$ and measured by spectronic at $600 \mathrm{~nm}$ every day to determine bacterial growth. Bacteria was cultivated by centifuge $(9820 \times g$ for $30 \mathrm{~min})$ after incubating single colony on $5 \%$ rice brand extract liquid medium at $37^{\circ} \mathrm{C}$ for $5 \mathrm{~d}$. Supernatant was presipitated by ammonium sulphate $(0-80 \%)$. The consentrared protein was collected by centrifuge $(16.260 \times g$ for $15 \mathrm{~min})$ and dialyzed with $5 \mathrm{mM}$ pH 7 Tris-Cl buffer.

Phytase Assay. Phytase activity was determined by measuring free phosphate after enzymatic reaction using modified method of Fiske \& Subbarow 1925. 200 L crude enzyme and 200 L substrate (sodium phytate $5 \mathrm{mM}$ in 50 $\mathrm{mM} \mathrm{pH} 7$ Tris-Cl buffer) were reacted for $10 \mathrm{~min}$ at $37^{\circ} \mathrm{C}$. Reaction was stopped by heating in boiling water for 30 min. Solution was mixed by vortex and centrifuged at $16.260 \times g$ for $10 \mathrm{~min}$. Supernatant (100 L) was dilluted 10 times by adding 900 L aquadest and reacted with $200 \mathrm{~L}$ dye solution for $30 \mathrm{~min}$. Dye reagent contained $5 \%$ ammonium heptamolybdate solution and $10 \%$ ascorbic acid in $1 \mathrm{M} \mathrm{H}_{2} \mathrm{SO}_{4}$ with 1:5 ratio. Absorbance of solution was determined by spectrophotometer at $\lambda 650 \mathrm{~nm}$. Unit activity was defined as the amount of enzyme to liberate 1 nmol free phosphate in $1 \mathrm{~min}$ and free phosphate standard was $\mathrm{K}_{2} \mathrm{HPO}_{4}(10-150 \mathrm{M})$.

Characterization of Phytase. Characterization of phytase was determined by measuring phytase activity at $50 \mathrm{mM}$ Na-acetate buffer $\mathrm{pH} 3,4,5,6$, and $50 \mathrm{mM}$ Tris-Cl buffer $\mathrm{pH} 7,8,9$. And also, temperature characteristic was determined by measuring phytase activity at 30, 37, 50, 60, 70,80 , dan $90^{\circ} \mathrm{C}$. Phytase mass molecular size profile was visualized by Commasie Briliant Blue coloring SDS-PAGE 
and phytase screening coloring Zymogram (Bae et al. 1999) using 5\% stacking gel and 12\% separating gel.

\section{RESULTS AND METHODS}

Phytase-Producing Bacteria from Chicken Manure.

Chicken manure was used to obtain phytase-producing bacteria. Screening of bacteria using $5 \%$ rice bran extract solid medium generated 4 kinds of bacteria colony (Figure 1a). There was no bacterial growth in the first day of incubation. The bacteria were observable since second day of incubation and it became obvious after several days. Therefore, bacteria were incubated for $5 \mathrm{~d}$ to gain better visualization.

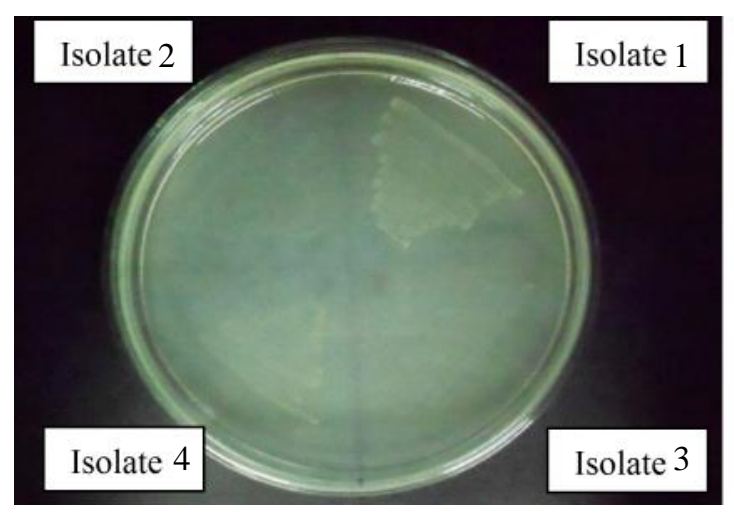

(a)
Determining phytase-producing bacteria was done by coloring the surface of bacterial growth medium using cobalt chloride, ammonium heptamolybdate, and sodium metavanadate (Bae et al. 1999). Clearing zone on the surface of bacterial growth medium indicated that the isolate was phytase-producing bacteria. Gram identification showed that isolate 1 was Gram negative bacteria which had coccus shape and did not have flagela.

Isolate 1 DNA chromosome was isolated by Wizard ${ }^{\circledR}$ Genomic DNA Purification Kit and amplified by PCR using universal primer BactF1 and UniB1 to produce $16 \mathrm{~S}$ rRNA gene. DNA fragment that showed on gel electrophoresis was about 1500 bp (Figure 2). DNA sequncing resulted

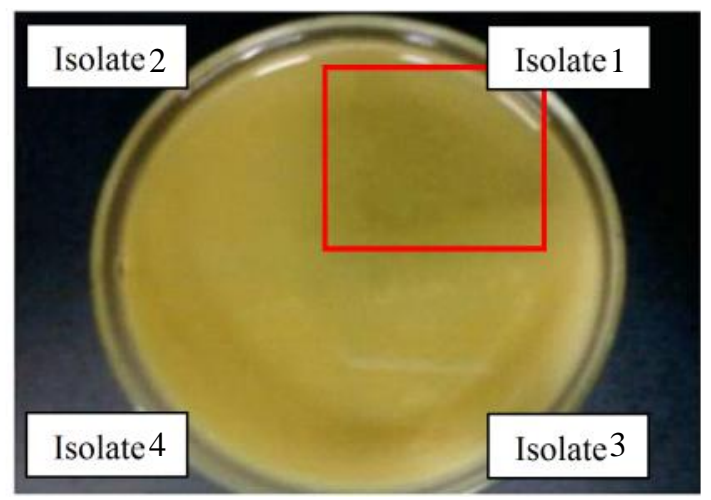

(b)

Figure 1 Screening of phytase-producing bacteria from chicken manure (a) profile of bacterial from chicken manure which incubated for $5 \mathrm{~d}$, and (b) profile of coloring screening of phytase-producing bacteria

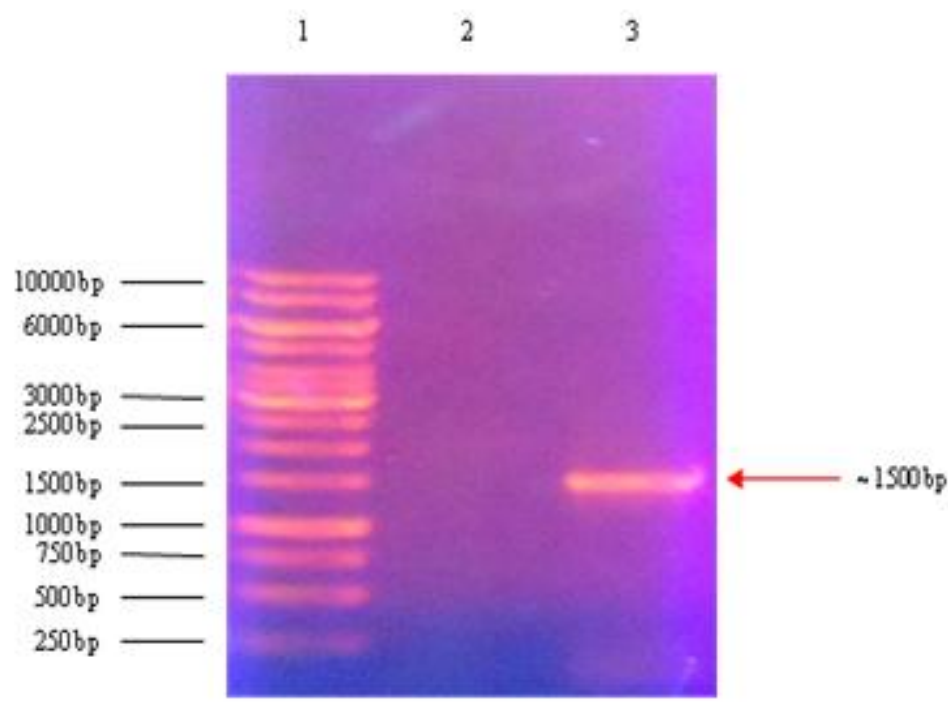

Figure 2 Electroforesis profile of 16S rRNA gene. (1) 1kb DNA Ladder (Fermentas). (2) Negative control. (3) Isolated and amplified DNA from isolate 1. 
1692 pb by BactF1 primer and 1606 bp by UniB 1 primer. Both of sequences was combined by Seqman and developed 1315 bp of $16 \mathrm{~S}$ rRNA gene.

Genetic relationship of isolate 1 with bacterial data on GeneBank was determined by BLAST on www.ncbi.nlm.nih.gov based on 16S rRNA gene sequence. It showed that isolate 1 had $99 \%$ maximum similarity with 100 kinds of Acinetobacter sp., such as Acinetobacter sp. DR.Y12 (GeneBank no. DQ226213.1), Acinetobacter oleivorans (GeneBank no. JX020951.1) dan Acinetobacter calcoacitecus (GeneBank no. JX164201.1). Phylogeny tree analysis based on 16S rRNA gene sequence of Acinetobacter genus was done by ClustalX and visualized by TreeView. Result showed that isolate 1 had genetic relationship with Acinetobacter calcoacitecus (Figure 3). Thus, isolate 1 which was obtained from screening of chicken manure bacteria was called Acinetobacter sp. TZ1.

Growth Characteristic of Acinetobacter sp. TZ1. Growth characteristic of Acinetobacter sp. TZ1 in 5\% rice bran extract liquid medium was shown in Figure 4. Bacteria adapted with the medium in the first day and went through doubling cell cleavage from second until forth day. Stationary phase of bacterial growth was reached at fifth day and death phase was started from sixth day of incubation. Bacterial growth was very slow because the medium for incubating the bacteria had minimum nutrition and the bacteria needed $5 \mathrm{~d}$ to reach maximum cell growth. Acinetobacter sp. TZ1 produced extracelullar phytase, and crude enzyme was obtained by collecting supernatant from cultivation of Acinetobacter sp. TZ1 on stationary phase of growth or at the bacteria reached maximum optical density (Figure 4).

Characteristic of Phytase TZ1. Phytase TZ1 activity was determined at several conditions of $\mathrm{pH}$ and temperature to obtain phytase characteristic. Phytase TZ1 activity reached optimum value wich achieved $69 \mathrm{nmol}$ $\min ^{-1} \mathrm{~mL}^{-1}$ at $\mathrm{pH} 5$ (Figure 5a). Phytase TZ1 activity was still obsevable about $70 \%$ at the $\mathrm{pH}$ range $3-7$, but the activity went down at $\mathrm{pH}>7$. This result indicated that phytase TZ1 was grouped in acid phosphatase.

On the other hand. Phytase TZ1 activity was observed at temperature range between $30-90^{\circ} \mathrm{C}$, and optimum activity was achived at $50^{\circ} \mathrm{C}$ which indicated that the phytase TZ1 was mesophylic enzyme (Fig 5b). Unit activity and spesific activity of phytase TZ1 at optimum

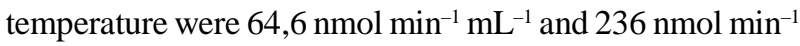
$\mathrm{mg}^{-1}$, respectively. Around $80 \%$ of the enzyme activity in hidrolyzing phytic acid was observable at $30^{\circ} \mathrm{C}$ and

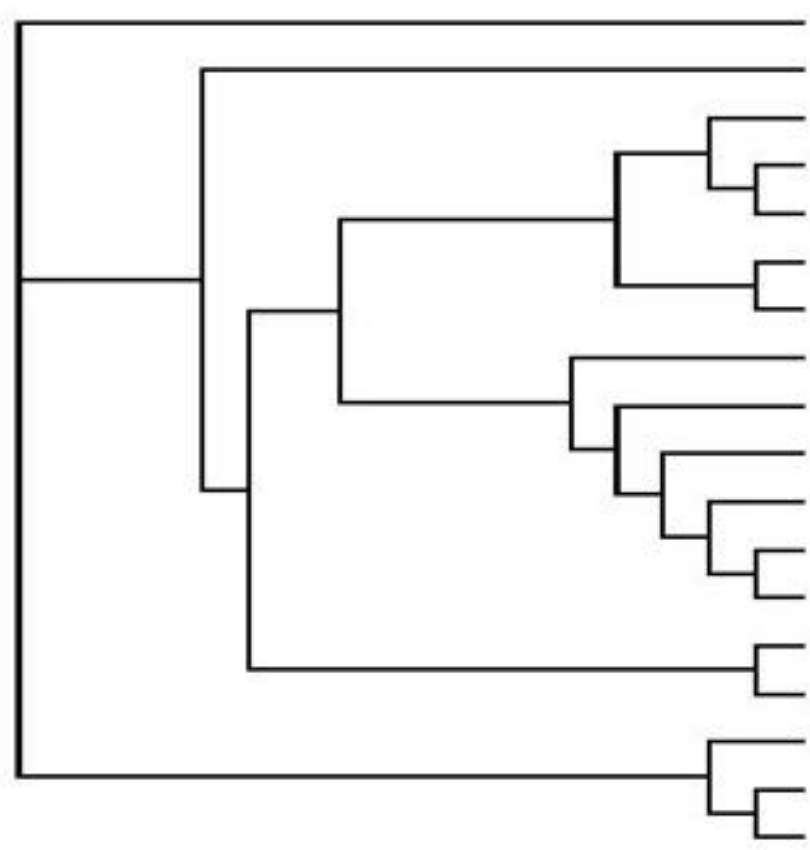

Acinetobacter junii FJ 544392.1

Acinetobacter tandoii JF304543.1

Acinetobacter towneri NR 028849.1

Acinetobacter baumannii $\mathbf{J} \times 290086.1$

Acinetobacter gerneri NR 028852.1

A.cinetobacter venetianus NR 042049.1

Acinetobacter radioresistens J.8898001.1

Acinetobacter ursingii NR 025392.1

Acinetobacter Iwoffii JX867755.1

Acinetobacter sp DR.Y12 DQ226213.1

Acinetobacter oleivorans JX020951.1

Acinetobacter calcoaceticus JX164201.1

Acinetobacter sp TZ1

Acinetobacter parvus AB720139.1

Acinetobacter tjernbergiae NR 028850.1

Acinetobacter schindleri NR 025412.1

Acinetobacter bouvet ii Jæ867756.1

Acinetobacter johnsanii $J \times 401452.1$

Figure 3 Phylogeny tree of Acinetobacter sp. TZ1 


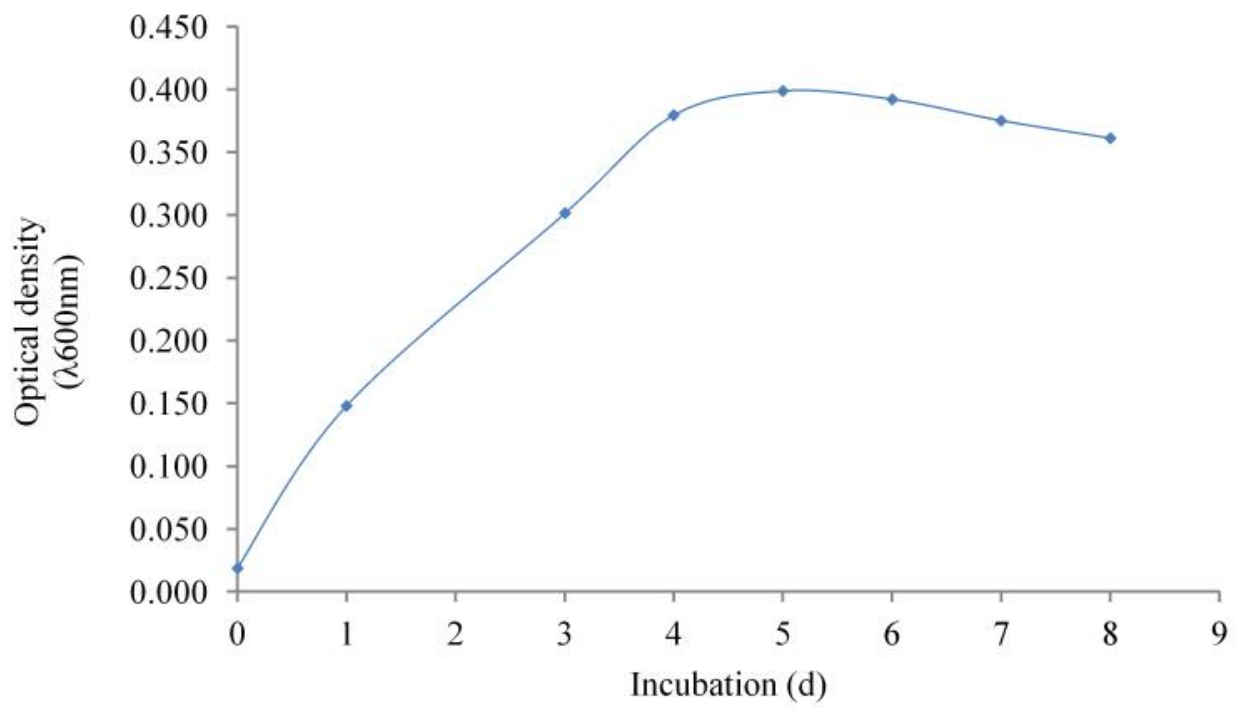

Figure 4 Growth profile of Acinetobacter sp. TZ1 in 5\% rice bran extract liquid medium

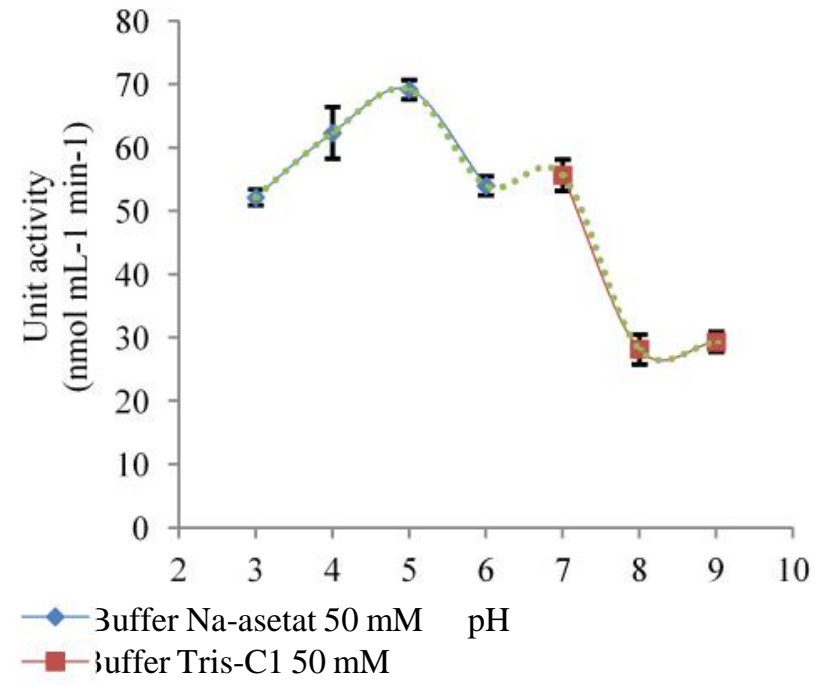

(a)

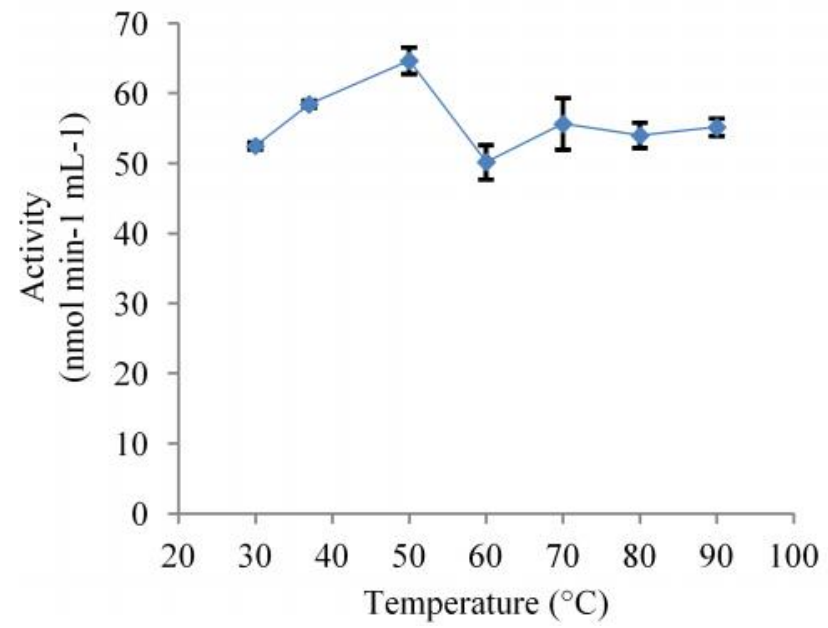

(b)

Figure 5 Phytase TZ1 activity. (a) Unit activity depend on several pH condition. (b) Unit activity depend on several temperature condition

temperature range between $60-90^{\circ} \mathrm{C}$. The phytase TZ1 characteristic was interesting for industrial application.

Mass molecular of phytase TZ1 was determined by SDS-PAGE (Figure 6). Protein band that was shown on the gel was about $35 \mathrm{kDa}$, but the real size of phytase TZ1 couldnot be determined yet. So that, protein band which appeared on gel couldnot be stated as the real mass molecular size of phytase TZ1.
Acinetobacter sp. TZ1 was coccus shape without flagela and Gram negative bacteria. It was grouped in $\gamma$ Proteobacteria sub-class and Moraxellaceae family, nonmotile, non-fermentative, strictly aerob, and its shape was about 1,5 m. Genus Acinetobacter had coccus or coccobacilli shape and was able to grow in low nutrition medium at temperature $37^{\circ} \mathrm{C}$ or below. The Acinetobacter sp. was difficult to differ because $16 \mathrm{~S}$ rRNA gene similarity among these species was high which was about $>97 \%$ (Visca et al. 2011). It had about 1500 bp of 16S rRNAgene 


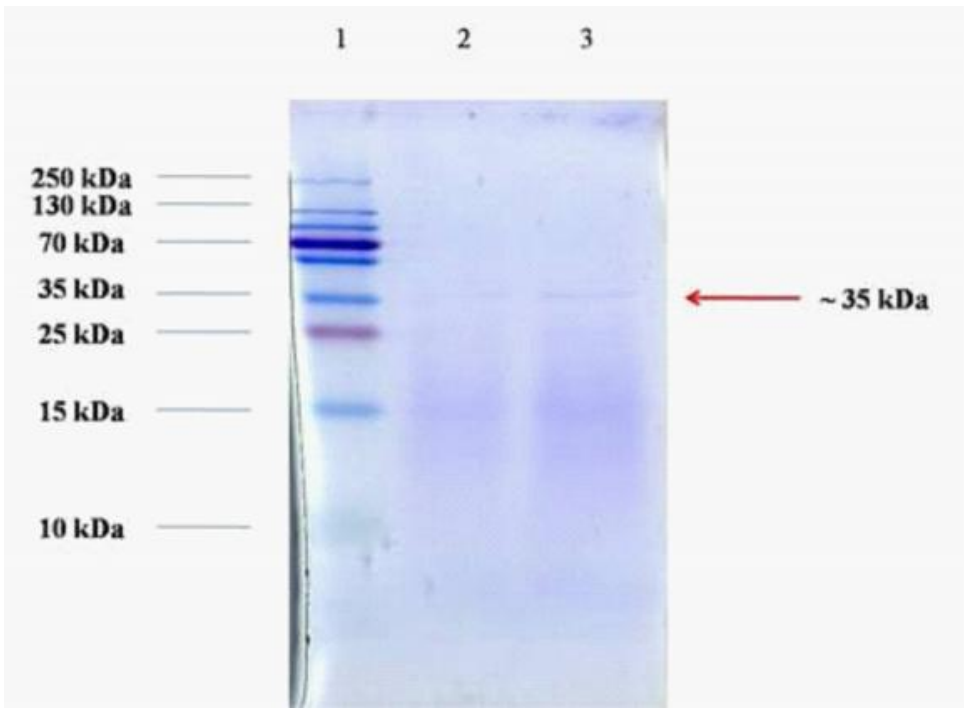

Figure 6 Relatif mass molecular profile of phytase TZ1 on SDS-PAGE and Zymogram. (1) Protein ladder. (2) $4.52 \mathrm{~g}$ concentrated protein. (3) 9.04 g concentrated protein

(Chang et al. 2005). The characteristics of Acinetobacter sp. were similar with the result of Acinetobacter sp. TZ1 identification in this study.

Acinetobacter sp. was able to grow in minimal salt medium containing triacontane (n-alcane with 30 carbon) at $28^{\circ} \mathrm{C}$ and it achived optical density about 0.6 after $5 \mathrm{~d}$ (Sakai et al. 1994). Moreover, it was capable to grow until $4 \mathrm{~d}$ in minimal salt medium containing $0.1 \%$ n-parafin (Koma et al. 2001).

Palacios et al. (2008) reported about bacteria that lived in chicken digestion track which was able to hidrolyze phytic acid. The result of his study said that screening of phytase-producing bacteria from chicken digestion track resulted Bifidobacterium dan Lactobacillus. These bacteria had specific activity at $\mathrm{pH} 5$ dan $50^{\circ} \mathrm{C}$ between

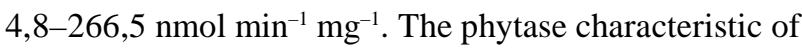
Palacios was similar with the characteristic of phytase that produced by Acinetobacter sp. TZ1.

Previous study which investigated phytase from chicken digestion tract couldnot determine the mass molecular size of phytase appropriately (Raghavendra \& Halami 2008; Palacios et al. 2008), but the mass molecular size of phytase produced by bacteria was about 10-55 kDa (Lei \& Porres 2003; Liu et al. 1998).

\section{CONCLUSIONS}

One bacterial colony which was screened from chicken manure was identified as phytase-producing bacteria. According to $16 \mathrm{~S}$ rRNA gene analysis, the isolate was named as Acinetobacter sp. TZ1. Phytase from Acinetobacter sp. TZ1 was assumed to have rellative mass molecular about $35 \mathrm{kDa}$, and it had optimum activity at $\mathrm{pH}$ 5 and $50^{\circ} \mathrm{C}$.

\section{ACKNOWLEDGMENTS}

Thank to Chemistry Department of Mathematic and Natural Science Faculty Institut Teknologi Bandung for supporting the study.

\section{REFERENCES}

Bae, H.D., Yanke, L.J., Cheng, K.J \& Selinger, L.B. 1999. A novel staining method for detecting phytase activity. J Microbiol Methodes (39): 17-22.

Bohn, L., Meyer, A.S \& Rasmussen, S.K. 2008. Phytate: impact on environment and human nutrition. A challenge for molecular breeding. J Zhejiang Univ SCIENCE B (3): 165-191.

Chang, H.C., Wei, Y.F., Dijkshoorn, L., Vaneechoutee, M., Tang, C.T \& Chang, T.C. 2005. Species-level identification of Acinetobacter calcoacitecusAcinetobacter baumanii complex by sequence analysis 
of the 16S-23S rRNA gene spacer region. J Clinical Microbiol (43): 1632-1639.

Fiske, C.H \& Subbarow, Y. 1925. The colometric determination of phosphorus. J Biol Chem (66): 375400.

Kerovuo, J., Lauraeus, M., Nurminen, P., Kalkkinen, N \& Apajalahti, J. 1998. Isolation, characterization, molecular gene cloning, and sequencing of a novel phytase from Bacillus subtilis. Appl Environ Microbiol 2079-2085.

Kerovuo, J., Rouvinen, J \& Hatzack, F. 2000. Analysis of myo-inositol hexakisphosphate hydrolysis by Bacillus phytase : indication of a novel reaction mechanism. Biochem J (352): 623-628.

Koma, D., Hasumi, F., Yamamoto, E., Ohta, T., Chung, S.Y \& Kubo, M. 2001. Biodegradation of long-chain nparaffin from waste oil of car engine by Acinetobactor sp. J Biosci Bioeng (91): 94-96.

Lei, X.G \& Porres, J.M. 2003. Phytase enzymology, application, and biotechnology. Biotechnol Letter (25): 1787-1794.

Liu, B.L., Rafiq, A., Tzeng, Y.M \& Rob, A. 1998. The induction and characteriszation of phytase and beyond. Enzyme and Microbial Technol (22): 415424.
Raghavendra, P \& Halami, P.M. 2009. Screening, selection and characterization of phytic acid degrading bacteria from chicken intestine. Intl J Food Microbiol (133): 129-134.

Sakai, Y., Maeng, J.H., Tani, Y \& Kato, N. 1994. Use of long-chain n-alkanes (C13 - C44) by an isolate Acinetobacter sp. M-1. Biosci Biotech Biochem (58): 2128-2130.

Tremaroli, V \& Bäckhed, F. 2012. Functional interactions between the gut microbiota and host metabolism. NATURE (489): 242-249.

Visca, P., Seifert, H \& Towner, K.J. 2011. Acinetobacter infection - an emerging threat to human health. IUBMB Life (63): 1048-1054.

Palacios, M.C., Haros, M., Sanz, Y \& Rosell, C.M. 2008. Selection of lactic acid bacteria with high phytate degrading activity for application in whole wheat breadmaking. LWT (41): 82-92. 